\title{
THE POLITICS OF BOTCHED EXECUTIONS
}

\author{
Corinna Barrett Lain *
}

For decades now, America's death penalty has been beset by serious problems in its administration, but what has finally gotten the public's attention is a spate of botched executions in the first half of 2014. "2014 is Already the Worst Year in the History of Lethal Injection" one headline blared after a fourth execution went awry in July. ${ }^{1}$ With fallout from botched executions named one of the "Top 10 Stories of 2014," there can be little doubt: the death penalty is once again in the spotlight, and botched executions are what put it there. ${ }^{2}$

Botched executions-executions beset by unanticipated problems or delays, often resulting in unnecessary pain for the condemned-are nothing new. ${ }^{3}$ Austin Sarat's timely book, Gruesome Spectacles, chronicles over a century of them. ${ }^{4}$ Indeed, Sarat's research shows that the botch rate for executions by lethal injection is over $7 \%$, more than double the botch rate of more antiquated

* Professor of Law and Associate Dean of Faculty Development, University of Richmond School of Law. Thanks to Jim Gibson for comments on an early draft, Cate Gray and Zack MacDonald for excellent research assistance, and to the University of Richmond Law Review for a fabulous symposium issue.

1. Ben Crair, 2014 Is Already the Worst Year in the History of Lethal Injection, New REP. (July 24, 2014), http://www.newrepublic.com/article/118833/2014-botched-execu tions-worst-year-lethal-injection-history.

2. Michelle Charles, Top 10 Stories of 2014-No. 4: Fallout from Botched Execution Brings Death Penalty Challenges, STILlWater News Press (Dec. 27, 2014, 6:00 AM), http: //www.stwnewspress.com/news/top-stories-of---no-fallout-from-botched-execution/article _b4606b8e-8d7d-11e4-ade6-b71e24a226fc.html.

3. Austin Sarat, Botched Executions Are Just Part of a Broken System, U.S. News \& WORLD REP. (July 28, 2014, 5:00 PM), http://www.usnews.com/debate-club/do-botched-exe cutions-make-the-case-for-abolishing-the-death-penalty/botched-executions-are-just-partof-a-broken-system.

4. Austin SARAT, Gruesome Spectacles: Botched Executions and America's DeATh PENAlty 5 (2014) [hereinafter SARAT, GRUESOME SPECTACLES]. 

been that way for decades. ${ }^{6}$

Although botched executions are hardly new, having to manage the public relations nightmare that has followed these increasingly high profile events is new, and tells a story of its own. What are the politics of botched executions? Officials have lowered the blinds so witnesses could not see what was happening in the execution chamber, ${ }^{7}$ called for an "independent review" by a nonindependent agency, ${ }^{8}$ minimized concerns by comparing the execution to the condemned's crimes, ${ }^{9}$ and even denied that a botched execution was botched in the first place. ${ }^{10} \mathrm{He}$ died, didn't $h e$ ?

In this symposium essay, I explore the politics of botched executions, discussing state responses to the latest round of executions gone wrong and the ways in which those responses matter. Part I recounts four botched executions in 2014 and the state responses that accompanied them. Part II makes three observations about those responses-one about states' fealty to the death penalty, one about backlash politics and the scope of the public relations problem, and one about the changing cultural construct of lethal injection in the United States. Part III explores how state responses to botched executions (or the lack thereof) might impact the constitutionality of lethal injection itself. In the end, the recent spate of botched executions may prove true the old adage

5. See id. at 120; Austin Sarat et al., Lethal Injection Leads to the Most Botched Executions, DAILY BEAST (Apr. 30, 2014), http://www.thedailybeast.com/articles/2014/04/30/le thal-injection-leads-to-the-most-botched-executions.html ("In recently completed research, we and our collaborators examined all American executions from 1890-2010. We found that 3 percent of those executions were botched in one way or another, from the slow strangulations and decapitations that occasionally occurred during hangings to the smoke and burning flesh of the electric chair to the agonizing death throes of those strapped to gurneys in lethal injection chambers. In fact, executions by lethal injection are botched at a higher rate than any of the other methods employed since the late-19th century, 7 percent.").

6. See Sarat, GRUeSome Spectacles, supra note 4, at 120 (discussing the rate of botched executions by lethal injection from 1980 to 2010).

7. See infra note 47 and accompanying text (discussing the botched execution of Clayton Lockett).

8. See infra notes 56-58 and accompanying text (discussing the botched execution of Clayton Lockett).

9. See infra note 77 and accompanying text (discussing the botched execution of Joseph Wood).

10. See infra notes $75-76$ and accompanying text (discussing the botched execution of Joseph Wood). 

"eview" by a nonomparing the exen denied that a .. ${ }^{10} \mathrm{He}$ died, didn't

cs of botched exeit round of execuresponses matter. and the state rehree observations to the death penof the public relatural construct of xplores how state hereof) might imIf. In the end, the rue the old adage

to the Most Botched Exe$\mathrm{m} /$ articles/2014/04/30/le atly completed research, 1890-2010. We found another, from the slow 5 hangings to the smoke oes of those strapped to injection are botched at ate-19th century, 7 per-

(discussing the rate of le botched execution of he botched execution of sotched execution of Johe botched execution of about politics making strange bedfellows. The inept executioner may prove the abolitionist's best friend.

\section{2014's FOUR BOTCHED EXECUTIONS}

The year 2014 got off to a quick start, at least in terms of botched executions. The first was Oklahoma's botched lethal injection of Michael Lee Wilson on January $9 .^{11}$ Wilson was convicted and sentenced to die for his part in the robbery and murder of a convenience store coworker. ${ }^{12}$ Oklahoma used a three-drug lethal injection protocol, but the first drug in the protocol-the anesthetic used to prevent pain-was pentobarbital, rather than the usual sodium thiopental, which had been discontinued in 2011 . $^{13}$ Whether the pentobarbital used was problematic because of the dosage or because it was a version of the drug produced by compounding pharmacies (which are not subject to FDA regulation and have been known to produce contaminated drugs ${ }^{14}$ is hard to say. What we know is that without adequate anesthesia, execution by lethal injection is excruciatingly painful, causing the condemned to experience a burning sensation, asphyxiation, muscle cramping, and cardiac arrest. ${ }^{15}$

And that brings us back to Wilson. When the warden ordered the execution to begin, Wilson uttered what he thought would be his last words, telling his mother, sister, and fiancée, "I love the

11. See Charlotte Alter, Oklahoma Convict Who Felt "Body Burning" Executed With Controversial Drug, TIME (Jan. 10, 2014), http://nation.time.com/2014/01/10/oklahoma-con vict-who-felt-body-burning-executed-with-controversial-drug/.

12. Id.

13. Id. For the story behind sodium thiopental's discontinuation in 2011, and the scramble for lethal injection drugs it set off, along with the implications of those developments, see generally James Gibson \& Corinna Barrett Lain, Death Penalty Drugs and the International Moral Marketplace, 103 GEO. L.J. _ _ (forthcoming 2015) (on file with author).

14. See Jennifer Gudeman et al., Potential Risks of Pharmacy Compounding, 13 DRUGS R.D. 1, 1-2 (2013), available at http://www.ncbi.nlm.nih.gov/pmc/articles/PMC362 7035/ (noting that drugs produced by compounding pharmacies are not subject to FDA regulations); see also Rick Lyman, Ohio Execution Using Untested Drug Cocktail Renews the Debate Over Lethal Injections, N.Y. TIMES, Jan. 17, 2014, at A15 (noting that the pentobarbital used in Wilson's execution came from a compounding pharmacy); cf. Lena $\mathrm{H}$. Sun, Officials: Pharmacy Knew About Contamination, WASH. POST, Oct. 27, 2012, at A2.

15. Alison Motluck, Execution by Injection Far From Painless, NEwSCIENTIST (Apr. 14, 2005, 3:49 PM), http://www.newscientist.com/article/dn7269-execution-by-injection-farfrom-painless.html\#VMIS2XZwPMe. 
world. Love my daughters for me. I'm going to miss you always."16 But those were not his last words. Twelve seconds into the execution, he uttered what would be his last words instead: "I feel my whole body burning." "17

As a sociopolitical phenomenon, what is perhaps most notable about the public reaction to Wilson's botched execution is that there wasn't one. Time Magazine reported the details of the botched execution on its website the next day, ${ }^{18}$ and the Associated Press reported Wilson's last words in passing, without mentioning that the execution had been botched..$^{19}$ But otherwise, the word was mum. The media did not mention it, the public was not outraged by it, the state had nothing to say about it. It was a nonevent.

Until the following week. That's when the second botched execution of 2014 occurred-Ohio's botched lethal injection of Dennis McGuire on January $16 .^{20}$ McGuire was convicted and sentenced to death for the rape and murder of a woman who was eight months pregnant. ${ }^{21}$ Ohio used an untested, two-drug lethal injection protocol consisting of the sedative midazolam and painkiller hydromorphone, which his attorneys had argued would cause an agonizing, terror-filled death. ${ }^{22}$ History appears to have proven them right. A typical execution by lethal injection takes between two to ten minutes. ${ }^{23}$ McGuire's execution took twenty-six, the

16. Alter, supra note 11.

17. Lyman, supra note 14.

18. See Alter, supra note 11 .

19. Compare Assoc. PREss, Oklahoma Executes Michael Lee Wilson for Murder of Convenience Store Worker, ENIDNEws.COM (Jan. 9, 2014, 10:05 PM), http://www.enidne ws.com/archives/oklahoma-executes-michael-lee-wilson-for-murder-of-convenience-store/a rticle_5b509d29-9bbb-5277-858b-d7d0e786613b.html (noting Wilson's last words in passing), with Rick Halperin, Oklahoma Executes Michael Lee Wilson, DEATH PENALTY NeWS (Jan. 10, 2014), http://deathpenaltynews.blogspot.com/2014/01/oklahoma-executes-michael -lee-wilson.html (reporting on Wilson's execution but not mentioning his last words).

20. See Assoc. Press, Executed Ohio Killer Dennis McGuire Took 15 Minutes to Die with Never-Before-Tried Drugs, N.Y. DAILY NEWS (Jan. 16, 2014, 11:53 AM), http://www. nydailynews.com/news/national/executed-ohio-killer-15-minutes-die-never-before-tried-dru gs-article-1.1581821.

21. Id.

22. Id.; see also Andrew Welsh-Huggins, Dennis McGuire, Killer, Will Face 'Agony and Terror' When Executed: Attorneys, HuFFINGTON POST (Jan. 8, 2014, 8:38 AM), http://www. huffingtonpost.com/2014/01/08/dennis-meguire-execution_n_4560739.html. For the story of why states have turned to untested lethal injection protocols, see Gibson \& Lain, supra note 13 .

23. SARAT, GRUESOME SPECTACLES, supra note 4, at 118. 
miss you always." 16 inds into the execuinstead: "I feel my

haps most notable execution is that the details of the 8 and the Associating, without menBut otherwise, the the public was not ut it. It was a non-

econd botched exeinjection of Dennis ted and sentenced an who was eight -drug lethal injecam and painkiller ad would cause an rs to have proven ion takes between k twenty-six, the

ee Wilson for Murder of PM), http://www.enidne r-of-convenience-store/a son's last words in pass, Death Penalty NeWS ahoma-executes-michael $\mathrm{ng}$ his last words).

Took 15 Minutes to Die 11:53 AM), http://www. ie-never-before-tried-dru

longest in Ohio's history. ${ }^{24}$ During the execution, McGuire gasped, choked, and repeatedly clenched his fists. ${ }^{25}$ Experts concluded that he likely suffered from a phenomenon known as "air hunger"- the struggle to satisfy the body and mind's urge to breathe. ${ }^{26}$

This time, the press was on it. Details of McGuire's final moments permeated the web, sometimes accompanied by recognition of Wilson's botched execution the week beforehand. ${ }^{27}$ Two weeks, two botched executions. Death penalty opponents seized on the opportunity to make hay, and state prison officials found themselves needing to move from their initial position of "no comment" on the execution. ${ }^{28}$ A spokesperson told the press, "The Department [of Corrections] remains confident ... that the inmate was completely unconscious and felt no pain," while stating that future executions would use higher dosages of midazolam and hydromorphone to "reaffirm" that the drugs would have their intended effect. ${ }^{29}$

If these had been the only botched executions of 2014, the public's short attention span almost certainly would have kept con-

24. Alan Johnson, Dennis McGuire's Execution Was Not 'Humane,' Doctor Says, Columbus Dispatch (Aug. 13, 2014, 7:19 AM), http://www.dispatch.com/content/stories/ local/2014/08/12/inmate-suffered-pain-during-execution-doctor-says.html.

25. Id.

26. See, e.g., John Caniglia, Dennis McGuire's Execution Raises Question in Debate Over Death Penalty: Why Is It So Hard to Put a Person to Death Humanely? CLEVELAND.COM (Jan. 26, 2014, 8:00 AM), http://www.cleveland.com/metro/index.ssf/ 2014/01/mcguires_execution_raises_key.html.

27. See Lawrence Hummer, I Witnessed Ohio's Execution of Dennis McGuire. What I Saw Was Inhumane, GUARDIAN (Jan. 22, 2014, 1:51 PM), http://www.theguardian.com/ commentisfree/2014/jan/22/ohio-mcguire-execution-untested-lethal-injection-inhumane; Alan Johnson, Inmate's Death Called 'Horrific' Under New, 2-Drug Execution, CoLumBus DiSPATCH (Jan. 17, 2014, 10:02 AM), http://www.dispatch.com/content/stories/local/2014/0 1/16/mcguire-execution.html; Nick O'Malley, Botched Ohio Execution Raises Death Penalty Dilemma, Sydney MoRNING HeRALD (Jan. 19, 2014), http://www.smh.com.au/world/bot ched-ohio-execution-raises-death-penalty-dilemma-20140119-hv92x.html; Gary Strauss, Ohio Killer's Slow Execution Raises Controversy, USA ToDAY (Jan. 16, 2014, 8:18 PM), http://www.usatoday.com/story/news/nation/2014/01/16/ohio-killer-executed-with-new-leth al-drug-combo/4512651/.

28. See Strauss, supra note 27 (quoting death penalty opponents and noting the prison's "no comment" position).

29. Tracy Connor, Ohio Says Controversial Execution of Dennis McGuire Was 'Humane,' NBC NEws (Apr. 28, 2014, 4:58 PM), http://www.nbcnews.com/storyline/lethalinjection/ohio-says-controversial-execution-dennis-mcguire-was-humane-n91811; Eric M. Johnson, Ohio Increases Death Penalty Drug Dosages After Execution Review, REUTERS (Apr. 29, 2014, 6:06 AM), http://www.reuters.com/article/2014/04/29/us-usa-execution-ohioidUSBREA3S09620140429. 
cerns from mounting. But they weren't the only ones. Two more botched executions followed in 2014, and they were more gruesome, more salacious, yet.

April 29, 2014, marks the moment that the public became truly transfixed by a botched execution. That's the date that Oklahoma executed Clayton Lockett (or at least tried) ${ }^{30}$ Lockett was convicted and sentenced to die for the murder, rape, kidnapping, and robbery of a young woman who was shot twice and then buried alive. ${ }^{31}$

The pending execution had already brought high drama. Oklahoma had initially refused to disclose the drugs that it would use in Lockett's execution, and even after relenting on that point, it steadfastly refused to disclose their source, citing a recently passed state law protecting the anonymity of lethal injection drug suppliers. ${ }^{32}$ Lockett's attorneys challenged the law and a district court ruled it unconstitutional, sending a stay-of-execution request to the criminal appeals court. ${ }^{33}$ The appeals court refused to grant it, stating that it had no pending litigation there: the challenge to the secrecy law was a civil action, and its jurisdiction was purely criminal. ${ }^{34}$ Lockett's attorneys then appealed to the state supreme court, which ordered its own stay of execution while the appeal of the ruling on the constitutionality of the state secrecy law was pending. ${ }^{35}$ Oklahoma's governor refused to honor the stay, saying that the state supreme court had no authority to issue it because the criminal appeals court had the final say on criminal issues (which it did, although the reason for the stay was civil, and thus properly before the state supreme court) ${ }^{36}$ A state

30. See Mark Berman, What it Was Like Watching the Botched Oklahoma Execution, WASH. POST (May 2, 2014), http://www.washingtonpost.com/news/post-nation/wp/2014/ 05/02/what-it-was-like-watching-the-botched-oklahoma-execution/.

31. See id.; Josh Levs et al., Oklahoma's Botched Lethal Injection Marks New Front in Battle Over Executions, CNN (Sept. 8, 2014, 7:16 AM), http://www.cnn.com/2014/04/30 /us/oklahoma-botched-execution/.

32. See Levs et al., supra note 31; Josh Sanburn, Oklahoma's 'Constitutional Crisis' Ends With Execution Date Set, Time (Apr. 25, 2014), http://time.com/75694/oklahomalethal-injection-date-lockett-warner-set/ [hereinafter Sanburn, Oklahoma's 'Constitutional Crisis'].

33. See Sanburn, Oklahoma's 'Constitutional Crisis,' supra note 32.

34. Id.; Erik Eckholm, Execution Case Roils Oklahoma Courts, N.Y. Times, Apr. 23, 2014, at A15.

35. See Sanburn, Oklahoma's 'Constitutional Crisis,'supra note 32.

36. See id.; Eckholm, Execution Case Roils Oklahoma Courts, supra note 34; Gail Sullivan, Fight Over Capital Punishment Is No Longer About Who Gets Executed, But How, 
y ones. Two more were more grue-

iblic became truly te that Oklahoma ckett was convictkidnapping, and and then buried

iigh drama. Oklathat it would use , on that point, it citing a recently hal injection drug law and a district $\mathrm{y}$-of-execution rels court refused to on there: the chals jurisdiction was ealed to the state recution while the the state secrecy sed to honor the to authority to isthe final say on $\mathrm{n}$ for the stay was e court). ${ }^{36} \mathrm{~A}$ state

ed Oklahoma Execution, ews/post-nation/wp/2014/

tion Marks New Front in Nww.cnn.com/2014/04/30

's 'Constitutional Crisis' ne.com/75694/oklahomalahoma's 'Constitutional

te 32 .

ts, N.Y. TIMES, Apr. 23, te 32.

supra note 34; Gail SulGets Executed, But How, legislator drafted articles of impeachment for the justices who issued the stay, and the state's attorney general called the situation a "constitutional crisis." "The crisis ended when the governor issued her own seven-day stay of execution, during which time the state supreme court decided that Oklahoma's secrecy law was constitutional after all. ${ }^{38}$ The title of one news article reporting on the fracas said it all: "Oklahoma Just Neutered Its State Supreme Court." 39

Given the drama beforehand, the press was primed and ready by the time Lockett's execution date rolled around. It did not go as planned. Oklahoma was using a new three-drug protocol, with midazolam as the first, anesthetic element. ${ }^{40}$ Ten minutes into the execution, a member of the execution team announced that Lockett was unconscious, a signal to proceed with the remaining drugs in the protocol. ${ }^{41}$ That's when the execution went haywire. Lockett's body started writhing and twitching. ${ }^{42}$ His foot kicked, then he clenched his jaw as his body buckled. ${ }^{43}$ He started rolling his head from side to side, mumbling the words "I'm not," "something's wrong," and "man. .." At one point, he opened his eyes. ${ }^{45}$ He began trying to lift his body off the gurney, as if to sit up. ${ }^{46}$ That's when officials closed the blinds to the viewing room. ${ }^{47}$

WASH. POST (Apr. 30, 2014), http://www.washingtonpost.com/news/morning-mix/wp/2014/ 04/30/fight-over-capital-punishment-is-no-longer-about-who-gets-executed-but-how/.

37. Eckholm, Execution Case Roils Oklahoma Courts, supra note 34; Sanburn, Oklahoma's 'Constitutional Crisis,' supra note 32.

38. Eckholm, Execution Case Roils Oklahoma Courts, supra note 34; Sanburn, Oklahoma's 'Constitutional Crisis,' supra note 32.

39. Andrew Cohen, Oklahoma Just Neutered Its State Supreme Court, WEEK (Apr. 29, 2014), http://theweek.com/articles/447457/oklahoma-just-neutered-state-supreme-court.

40. Levs et al., supra note 31 . For the story of why states are using new, untested lethal injection protocols, see generally Gibson \& Lain, supra note 13.

41. Josh Sanburn, 25 Secret Minutes Inside Oklahoma's Execution Chamber, TIME (May 1, 2014), http://time.com/82787/oklahoma-botched-execution-clayton-lockett-lethal-in jection-problems/ [hereinafter Sanburn, 25 Secret Minutes]; see also Berman, supra note 30.

42. Sanburn, 25 Secret Minutes, supra note 41.

43. Berman, supra note 30 .

44. Id.; Levs et al., supra note 31 .

45. See Sanburn, 25 Secret Minutes, supra note 41.

46. See id.; Levs et al., supra note 31.

47. Berman, supra note 30; Sanburn, 25 Secret Minutes, supra note 41. 
Behind the scenes, a member of the execution team checked Lockett's IV and discovered that the line had blown. ${ }^{48}$ Lockett's vein had collapsed, and according to Oklahoma's Department of Corrections, "[T] $]$ he drugs had either absorbed into tissue, leaked out or both." witnesses to leave. ${ }^{50}$ Forty-three minutes after the execution had begun, Lockett was dead. ${ }^{51}$ Officials initially stated that he died of a heart attack, but an autopsy later stated that lethal injection was responsible for his death. ${ }^{52}$

The press had a field day, often noting the earlier botched executions of McGuire and Wilson in its coverage. ${ }^{53}$ As the incident began to draw worldwide attention, the White House press secretary issued a statement: "We have a fundamental standard in this country that even when the death penalty is justified, it must be carried out humanely-and I think everyone would recognize that this case fell short of that standard. ${ }^{154}$

Oklahoma's governor held a press conference as well. She began with a lengthy recitation of Lockett's crimes, followed by a statement of her support for the death penalty as an appropriate response. ${ }^{55}$ She then recognized the state's need to be certain that its execution protocols worked, announcing that she had tapped her public safety commissioner to conduct an "independent review" of the incident and that she would stay further executions

\footnotetext{
48. Levs et al., supra note 31 .

49. Berman, supra note 30.

50. See id.; Levs et al., supra note 31 .

51. See Levs et al., supra note 31 .

52. Berman, supra note 30; Josh Sanburn, Oklahoma Death Row Inmate Died From Lethal Injection, Not Heart Attack, TIME (Aug. 28, 2014), http://time.com/3211135/claytonlockett-autopsy-lethal-injection/.

53. See, e.g., Berman, supra note 30; Levs et al., supra note 31; Michael Overall, National, World Media Offer Reactions to Failed Execution, TULSA WORLD (May 1, 2014, 12:00 AM), http://www.tulsaworld.com/news/state/national-world-media-offer-reactions-tofailed-execution/article_70339660-d0b4-11e3-a98b-0017a43b2370.html; Sanburn, 25 Secret Minutes, supra note 40; Wide Outcry Condemns Botched Execution in Oklahoma, DALL. MoRNING NEws (May 1, 2014, 12:06 AM), http://www.dallasnews.com/news/metro/2014 0430-wide-outcry-condemns-botched-execution-in-oklahoma.ece.

54. See Berman, supra note 30 (noting worldwide attention on United States death penalty from Lockett's botched execution); Levs et al., supra note 31.

55. See Levs et. al., supra note 31; Oklahoma Governor Says Execution Probe Will Be 'Independent,' NBC NEWS (Apr. 30, 2014), http://www.nbcnews.com/storyline/lethal-inject ion /oklahoma-governor-says-execution-probe-will-be-independent-n93886.
} 
tion team checked . blown. ${ }^{48}$ Lockett's เa's Department of into tissue, leaked process and asked the execution had ited that he died of tat lethal injection

arlier botched exe$:^{53}$ As the incident House press secreental standard in is justified, it must te would recognize

e as well. She benes, followed by a as an appropriate to be certain that at she had tapped "independent refurther executions

Row Inmate Died From me.com/3211135/clayton-

31; Michael Overall, $\mathrm{Na}$ A WoRLD (May 1, 2014, media-offer-reactions-toatml; Sanburn, 25 Secret ion in Oklahoma, DALL. ws.com/news/metro/2014

on United States death 1.

Execution Probe Will Be $\mathrm{m} /$ storyline/lethal-inject n93886.

until the review was completed. ${ }^{56}$ The Public Safety Commissioner is a member of the governor's cabinet and reports directly to her. ${ }^{57} \mathrm{He}$ also oversees Oklahoma's prisons, is a former employee of Oklahoma's Department of Corrections, and was in the execution chamber when Lockett was executed. ${ }^{58}$ The review concluded that Oklahoma's execution system was fundamentally sound; the execution team had simply "misplaced" Lockett's IV. ${ }^{59}$

After Lockett's botched execution, it was hard to imagine an execution going more wrong, but then came Arizona's botched lethal injection of Joseph Wood on July $23 .^{60}$ Wood was convicted and sentenced to die for the murder of his estranged girlfriend and her father. ${ }^{61}$ When Arizona announced it would be using the same two-drug protocol of midazolam and hydromorphone that had been used in Lockett's execution, his lawyers challenged the protocol. ${ }^{62}$ They lost, and the execution proceeded as scheduled. ${ }^{63}$ But once again, it did not go as planned.

Four minutes into the execution, a member of the execution team announced that Wood was sedated. ${ }^{64}$ Shortly thereafter, Wood's lips moved and he started gasping for air, taking deep, long breaths "like he was drowning." "He gulped like a fish on

\section{See id.}

57. See Oklahoma Governor Says Execution Probe Will Be 'Independent,' supra note 55; Richard L. Fricker, Oklahoma's Execution De-Botch-ery, OKLA. OBSERVER (Apr. 30, 2014), http://www.okobserver.net/2014/04/30/oklahomas-execution-de-botch-ery/.

58. Andrew Cohen, After Oklahoma's Botched Execution, Here Comes the Cover-Up, WEEK (May 7, 2014), http://theweek.com/articles/447185/after-oklahomas-botched-executi on-here-comes-coverup [hereinafter Cohen, After Oklahoma's Botched Execution]; Erik Eckholm, IV Misplaced in Oklahoma Execution, Report Says, N.Y. TIMES, Sept. 5, 2014, at A14 [hereinafter Eckholm, IV Misplaced]; Fricker, supra note 57.

59. See Eckholm, IV Misplaced, supra note 58. For the full report see OKLA. DEP'T Pub. SAfety, The ExeCution of Clayton D. Lockett (2014), available at http://ny times.com/interactive/2014/09/05/us/05execute-doc.html.

60. See Erik Eckholm, Arizona Takes Nearly 2 Hours to Execute Inmate, N.Y. TIMES, July 24, 2014, at A1.

61. Id.

62. See Michael Kiefer, Reporter Describes Arizona Execution: 2 Hours, 640 Gasps, AZ CENT. (Nov. 6, 2014, 10:01 AM), http://www.azcentral.com/story/news/arizona/politics/20 14/07/24/arizona-execution-joseph-wood-eyewitness/13083637/ [hereinafter Kiefer, Reporter Describes Arizona Execution].

63. See id.

64. Id.

65. Josh Sanburn, Inside the Efforts to Halt Arizona's Two-Hour Execution of Joseph Wood, TIME (July 24, 2014), http://time.com/3026985/joseph-wood-arizona-lethal-injectionbotched/ [hereinafter Sanburn, Inside the Efforts to Halt Arizona]. 
land," one reporter stated, adding, "The movement was like a piston: The mouth opened, the chest rose, the stomach convulsed." ${ }^{\prime 66}$ It happened over 640 times. $^{67}$

An hour into the execution, Wood's attorneys filed an emergency petition to stop it. ${ }^{68}$ A representative from the Arizona Attorney General's office told the federal district court where it was filed that there was no point, as Wood had already been given a second dose of lethal injection drugs and was "effectively brain-dead." Wood died before the court could issue a ruling, an hour and fiftyseven minutes after his execution began. ${ }^{70}$ Records revealed that the execution team had given Wood fifteen doses of lethal injection drugs. ${ }^{71}$

The public outcry that followed was deafening. ${ }^{72}$ Even Arizona Senator John McCain described Wood's execution as a "bollocksupped situation" that amounted to "torture," although he later

66. Kiefer, Reporter Describes Arizona Execution, supra note 62.

67. Id.

68. See Sanburn, Inside the Efforts to Halt Arizona, supra note 65.

69. Michael Kiefer, Arizona Officials Deny Execution Was Botched, Az. CENT. (July 25, 2014, 9:09 AM), http://www.azcentral.com/story/news/arizona/politics/2014/07/25/arizonaofficials-deny-execution-botched/13145329/ [hereinafter Kiefer, Arizona Officials Deny].

70. See id. (stating that Wood died before the assistant attorney general's conversation with the district court judge was finished); see also Matt Ford, One Hour and 57 Minutes in Arizona, ATLANTIC (July 24, 2014, 7:48 AM), http://www.theatlantic.com/poli tics/archive/2014/07/one-hour-and-fifty-seven-minutes-in-arizona/374951/ (indicating that Wood's execution lasted one hour and fifty-seven minutes).

71. See Cindy Carcamo, After First Drug Dose Failed to Kill Arizona Inmate, Logs Show 14 More, L.A. Times (Aug. 2, 2014, 9:46 PM), http://www.latimes.com/nation/nation now/la-na-nn-arizona-botched-execution-15-doses-20140801-story.html; Fernanda Santos, Executed Arizona Inmate Got 15 Times Standard Dose, Lawyers Say, N.Y. TIMES, Aug. 2, 2014, at A11.

72. See, e.g., David Schwartz, Two-Hour Arizona Execution Sparks Calls for Rethink on Death Penalty, ReUTERS (July 24, 2014, 12:54 PM), http://cnews.canoe.ca/CNEWS/ World/2014/07/24/21829556.html (citing concerns from the Arizona governor); Botched Execution Demonstrates Debacle of Death, SFGate (July 24, 2014, 5:56 PM), http://www.sf gate.com/opinion/editorials/article/Botched-execution-demonstrates-debacle-of-death-5645 595.php (" $[E]$ ven the majority of Americans who are ambivalent to enthusiastic about capital punishment should be sickened by descriptions of Wednesday's debacle in Arizona."); 2-Hour Arizona Execution Stirs Controversy, TODAY (July 24, 2014), http://www.today.com/ video/today/55713305\#55713305 (referencing outcry from the ACLU); DEMOCRACY NOW, Botched 2 Hour Arizona Execution Fuels Outrage Over Lethal Injection Methods, FSTV (July 24, 2014, 12:44 PM), https://www.freespeech.org/video/botched-2-hour-arizona-execution -fuels-outrage-over-lethal-injection-methods (discussing the botched execution generally).

73. Burgess Everett, John McCain: Arizona Execution 'Torture,' PoliTiCo (July 24, 2014, 4:59 PM), http://www.politico.com/story/2014/07/john-mccain-arizona-execution-1093 50.html. 

where it was filed :en given a second rely brain-dead." "69 an hour and fiftyords revealed that es of lethal injec-

g. ${ }^{72}$ Even Arizona on as a "bollocksalthough he later

softened that descriptor. "I don't know if it's exactly "torture," he said, "Rather than use 'torture,' I think I'd rather use the wording that it's not humane." 74

But Arizona Department of Corrections officials had a different take, denying that Wood's execution was botched in the first place and calling media reports to the contrary "premature and erroneous." 75 According to officials, the execution was not botched because Wood was "comatose and never in pain." Arizona's governor agreed, telling the press, "One thing is certain, however, inmate Wood died in a lawful manner and by eyewitness and medical accounts he did not suffer. This is in stark comparison to the gruesome, vicious suffering that he inflicted on his two victims-and the lifetime of suffering he has caused their family." The governor announced that she had nevertheless directed the Department of Corrections to review its execution process, which it did. $^{78}$ The ensuing report concluded that Wood's execution was conducted in accordance with proper procedures and that his gasps were "normal bodily responses to dying."79 Nothing went wrong, the report stated, but Arizona would likely alter its lethal injection protocol in future executions. ${ }^{80}$

65.

hed, Az. CENT. (July 25, itics/2014/07/25/arizonazona Officials Deny]. "ney general's conversaord, One Hour and 57 ww.theatlantic.com/poli 74951/ (indicating that

I Arizona Inmate, Logs imes.com/nation/nation tml; Fernanda Santos, ay, N.Y. TIMES, Aug. 2,

parks Calls for Rethink news.canoe.ca/CNEWS/ governor); Botched Ex:56 PM), http://www.sf -debacle-of-death-5645 enthusiastic about caps debacle in Arizona."); http://www.today.com/ U); DEMOCRACY NOW, ion Methods, FSTV (Juhour-arizona-execution execution generally). re,' POLITICO (July 24, arizona-execution-1093

And with that, 2014's spate of botched executions came to an end. The rest of the year was relatively quiet, with just nine executions in the last five months of $2014 .^{81}$ That put 2014's year-end

74. Dan Nowicki, McCain Backs Off Assertion That Execution Was Torture, AZCENTRAL.COM (July 28, 2014, 5:44 PM), http://www.azcentral.com/story/azdc/2014/07/ 28/mccain-backs-off-botched-execution-torture-claim/13297877/.

75. See Kiefer, Reporter Describes Arizona Execution, supra note 62.

76. Id.

77. Dana Ford et al., Another Botched Execution? Inmate Gasps During Two-Hour Execution, CNN (Sept. 8, 2014, 7:16 AM), http://www.cnn.com/2014/07/23/justice/arizona-exec ution-controversy/.

78. See id.; Editorial Board, Sure, THIS Will Be a Thorough Investigation, AZCENTRAL.COM (July 26, 2014, 4:18 PM), http://www.azcentral.com/story/opinion/edito rial/2014/07/25/joseph-rudolph-wood-execution-investigation/13194255/ (“Our View: Prison director says Joseph Rudolph Wood's execution wasn't botched. But he's committed to 'comprehensive review'? Riiiiight. ... Excuse us if we have no confidence it will be anything more than a whitewash.").

79. Michael Kiefer, Arizona: Wood Execution Not Botched, But Drug Cocktail to Change, AzCENTRAL.COM (Dec. 23, 2014, 8:42 AM), http://www.azcentral.com/story/news/ local/arizona/2014/12/22/arizona-execution-drug-change/20774877/.

80. See id.

81. Execution List 2014, DEATH PENALTY INFO. CTR., http://www.deathpenaltyinfo.org/ execution- list-2014 (last visited Feb. 27, 2014). 
total number of executions at thirty-five, the lowest annual tally in twenty years. ${ }^{82}$

\section{Three Observations About the Politics of Botched EXECUTIONS}

The year 2014 is notable not only for its botched executions, but also for the politics that accompanied them. Going into 2014, the politics of botched executions were quiet, virtually nonexistent. Michael Lee Wilson's botched execution drew no public attention, and demanded no public relations response. That started to change with Dennis McGuire's execution a week later, and by Clayton Lockett's botched execution in April, the politics that permeate the death penalty more generally had found their way to botched executions too. Looking back at 2014, what might we say about the politics of botched executions, aside from the fact that they now exist?

At least three observations come to mind. The first is about states' fealty to the death penalty. What was striking about the state responses to 2014's botched executions was how strident officials were in denying there was a problem, how resolute they were in protecting the process from meaningful inquiry, how committed they were to defending the execution at all costs. Ohio stating it was confident that Dennis McGuire suffered no pain, Arizona claiming that its execution of Joseph Wood was not botched-as if just stating a proposition could make it so. Oklahoma literally closing the blinds so no one could see what was happening, then figuratively closing them with an "independent review" by a non-independent arm of the state.

The epitome of this phenomenon is the press conference where Arizona denied that Joseph Wood's execution had been botched. A Department of Corrections official gave a statement to the press, then refused to take questions and turned to walk away from the mic. $^{83}$ But as he was leaving, a member of the press asked him,

82. Executions by Year, DEATH PENALTY INFO. CTR., http://www.deathpenaltyinfo.org/ executions-year (last visited Feb. 27, 2014).

83. See Arizona Prison Chief Says Execution Wasn't Botched, AzFAMILY.COM (July 24, 2014), http://www.azfamily.com/home/Arizona-prison-chief-says-execution-wasnt-botched-268539802.html. 
"How is a two-hour execution not botched?" The question lingered in the air, unanswered.

A similar scene played out when Oklahoma's governor read her statement to the press in the wake of Clayton Lockett's botched execution and then refused to take questions, either about the execution or the so-called "independent" review she had just announced. ${ }^{85}$ She came under heavy fire for that non-independent independent investigation, but resolutely pushed forward, feeling no compunction to answer critics' claims. ${ }^{86}$ Did she even have an answer?

This phenomenon is perplexing. Public Relations 101 teaches that when something goes wrong, the politically correct response is to take responsibility, and take action to fix it. That feels very different from what we are seeing here-state responses that minimize, deny, and paper over the problem, with little regard for the public relations implications along the way. Why the disconnect?

The answer may be what my colleague Jim Gibson calls the "religion of the death penalty"-a blind faith in the sanctity of the death penalty and its processes despite the absence of facts supporting that belief on the ground. The accused didn't suffer, the execution wasn't botched. State officials won't take questions not only because they don't have answers, but also because no answers are needed on matters of unquestioned faith. Either you believe in the death penalty, in which case you see botched executions as a necessary cost of doing business-or you don't, in which case no state response short of abolition will soothe you. The politics of botched executions are not about public relations; they are

onference where been botched. A ent to the press, $\mathrm{k}$ away from the ress asked him,

85. See Gov. Mary Fallin Calls for Independent Execution Review, NEWS9.COM, http://www.news9.com/clip/10109114/govmary-fallin-calls-for-independent-execution-re view (last visited Feb. 27, 2015).

86. See, e.g., Cohen, After Oklahoma's Botched Execution, supra note 58 ("[T] reason to think this important inquiry will be remotely 'independent,' . . . No investigation in which the chief investigator is also a material fact witness is worthy of any credibility or respect."); Rick Green, Botched Execution: Gov. Fallin Labels Investigation 'Independent' Though It's Led by State Official Present at Lethal Injection, NewsOK (May 2, 2014), http: //newsok.com/botched-execution-gov.-fallin-labels-investigation-independent-though-itsled-by-state-official-present-at-lethal-injection/article/4745704/?page=2; Bryan Newell, Governor Fallin's Proposed Investigation Is Not Independent, ACLU OKLA. (Apr. 30, 2014, 6:13 PM), http://acluok.org/2014/04/governor-fallins-proposed-investigation-is-not-indepen dent/; Oklahoma Governor Says Execution Probe Will be 'Independent,'supra note 55. 
about states' commitment to the death penalty. In the face of weakness, they show strength.

A second observation is that 2014's high-profile botched executions and the political responses accompanying them have, in turn, given rise to backlash politics of their own. States' responses to botched executions have given critics even more to criticize, and a new narrative to sell-one that turns from the wrongs of the offender to the wrongs of the state, from the need for retribution to the need for procedural protections. States shield their protocols from meaningful scrutiny, ${ }^{87}$ use untested drugs from undisclosed providers, ${ }^{88}$ rush to execute while litigation is still underway $^{89}$ - even threaten to impeach judges who step into the fray. ${ }^{90}$ Against the backdrop of botched executions, states' fealty to the death penalty and its processes makes a compelling case for the need for restraint.

Indeed, the backlash politics of botched executions have moved beyond botched executions, drawing renewed attention to the death penalty's other perceived failings. President Barack Obama's announcement that the Justice Department would be conducting a full-scale review of the death penalty in the wake of Clayton Lockett's botched execution is a prime example. ${ }^{91}$ Speaking to the press, Obama said:

87. Andrew Cohen, Oklahoma's Courts Are at War Over Lethal-Injection Secrecy, ATLANTIC (Apr. 21, 2014, 1:55 PM), http://www.theatlantic.com/national/archive/2014/ 04/Oklahoma/360940/ ("You cannot sustain an Eighth Amendment claim here unless you can establish that the drugs to be used will cause pain to the condemned .... and you cannot prove that they'll cause pain because you have no right to demand that state officials share information about the drugs with you.... The conflict today is about secrecy and transparency-not guilt or innocence or crime or punishment.").

88. See Tara Lai Quinlan, Relying on Untested Execution Drugs Raises Important Health, Safety and Human Rights Concerns, HuFFington Post (Dec. 23, 2013, 10:01 AM), http://www.huffingtonpost.com/tara-lai-quinlan/untested-execution-drugs_b_4490351.html (discussing various concerns about compounded drugs and compounding pharmacies).

89. See Mike Littwin, The Rush to More Botched Executions, CoLO. INDEP. (May 2, 2014), http://www.coloradoindependent.com/147293/littwin-the-rush-to-more-botched-exec utions.

90. Cohen, Oklahoma Just Neutered Its State Supreme Court, supra note 39 (discussing constitutional showdown that preceded botched Clayton Lockett execution and impeachment proceedings instituted against the five Oklahoma Supreme Court Justices who granted a stay in the case, and who, two days after, lifted it).

91. See Ben Wolfgang, Obama: Time for 'Difficult and Profound Questions' About the Death Penalty, WASH. TIMES (May 2, 2014), http://www.washingtontimes.com/news/2014 /may/2/obama-justice-dept-review-death-penalty-procedures/print/. 
file botched execung them have, in . States' responses more to criticize, 'om the wrongs of ə need for retributates shield their ested drugs from litigation is still who step into the ons, states' fealty a compelling case

tions have moved attention to the 'resident Barack rtment would be lty in the wake of example. ${ }^{91}$ Speak-

ethal-Injection Secrecy, /national/archive/2014/ claim here unless you mned ... and you canand that state officials $y$ is about secrecy and

rugs Raises Important c. 23, 2013, 10:01 AM), drugs_b_4490351.html ding pharmacies).

COLO. INDEP. (May 2, 1-to-more-botched-exec

upra note 39 (discussett execution and imne Court Justices who atimes.com/news/2014
I've said in the past that there are certain circumstances in which a crime is so terrible that the application of the death penalty may be appropriate-mass killings, the killings of children. But I've also said that in the application of the death penalty in this country, we have seen significant problems-racial bias, uneven application of the death penalty, situations in which there were individuals on death row who later on were discovered to have been innocent.... all these I think do raise significant questions about how the death penalty is being applied. And this situation in Oklahoma I think just highlights some of the significant problems there.... I think we do have to, as a society, ask ourselves some difficult and profound questions....

Those questions were not new. What was new was the President asking them.

A third and final observation about the politics of botched executions regards the changing cultural construct of lethal injection in the United States. Before 2014's spate of botched executions, lethal injection was widely viewed as painless, peaceful-like putting down a beloved pet. ${ }^{93}$ Not so today. 2014's botched executions exposed the violence inherent in taking human life, and the façade of lethal injection in masking it. As Chief Judge Alex Kozinski of the Ninth Circuit Court of Appeals put the point:

Using drugs meant for individuals with medical needs to carry out executions is a misguided effort to mask the brutality of executions by making them look serene and peaceful-like something any one of us might experience in our final moments. But executions are, in fact, nothing like that. They are brutal, savage events, and nothing the state tries to do can mask that reality. Nor should it. ... [I]f we are willing to carry out executions, we should not shield ourselves from the reality that we are shedding human blood. ${ }^{94}$

In the wake of 2014's botched executions, numerous op-eds, commentaries, and news articles agreed. ${ }^{95}$ Botched executions were a

92. Remarks by President Obama and German Chancellor Merkel in Joint Press Conference, OFF. PRESS SEC'Y (May 2, 2014), http://www.whitehouse.gov/the-press-office/2014 105/02/remarks-president-obama-and-german-chancellor-merkel-joint-press-confere.

93. Indeed, that was the point. See, e.g., Greg Mitchell, How Lethal Injections Became the Go-To Method for Executions in America, NATION (May 9, 2014, 2:02 PM), http://www. thenation.com/blog/179777/how-lethal-injections-became-go-method-executions-america\#.

94. Wood v. Ryan, 759 F.3d 1076, 1102-03 (9th Cir. 2014) (Kozinski, C.J., dissenting from denial of rehearing en banc) (citations omitted).

95. See, e.g., Editorial, The Myth of the Compassionate Execution, SCI. AM., May 2014, at 12, 12 (republished as Let's Stop Pretending the Death Penalty Is a Medical Procedure, available at http://www.scientificamerican.com/article/lets-stop-pretending-the-death-pen alty-is-a-medical-procedure-editorial/); Jonathan P. Baird, My Turn: Making the Death 
vivid reminder of the brutality of the death penalty, but the brutality of state-imposed death had always been there-botched execution or not. ${ }^{96}$

As Austin Sarat writes in Gruesome Spectacles, it is not the fact of botched executions but rather their "cultural reception" that defines the impact they have in the larger sociopolitical discourse. ${ }^{97}$ Are botched executions merely misfortunes? Or do they challenge the legitimacy of the executing state? ${ }^{98}$ Interestingly, Sarat concludes that botched executions have not moved public sentiment, or even played a role in abolitionist politics ${ }^{99}$-and he was undoubtedly right when he was writing his book. Ironically, the year it was published, 2014, is the year that characterization became no longer true.

\section{STATE RESPONSES TO BotCheD ExECUTIONS AND THE CONSTITUTIONALITY OF LETHAL INJECTION}

In the final part of this essay, I ask how state responses to botched executions (or the lack thereof) might impact the constitutionality of lethal injection itself. At the time of this writing,

Penalty Even More Barbaric, CONCORD MONITOR (June 4, 2014), http://www.concord monitor.com/home/12213622-95/my-turn-making-the-death-penalty-even-more-barbaric; James Downie, Opinion, Oklahoma's Horrible 'Botched Execution' Shows Again Why the Death Penalty Should Be Abolished, WASH. PosT (Apr. 30, 2014), http://www.washingtonpost. com/blogs/post-partisan/wp/2014/04/30/oklahomas-horrible-botched-execution-shows-again -why-the-death-penalty-should-be-abolished/; Jesse Wegman, Opinion, There is No Such Thing As a 'Clean' Execution, N.Y. TIMES (June 5, 2014, 2:24 PM), http://takingnote. blogs.nytimes.com/2014/06/05/there-is-no-such-thing-as-a-clean-execution/?_r=0; Opinion, Botched Execution Demonstrates Debacle of Death, SFGATE (July 24, 2014, 5:56 PM), http: //www.sfgate.com/opinion/editorials/article/Botched-execution-demonstrates-debacle-ofdeath-5645595.php; Editorial, 'Botching It' Just Grisliest Argument Against Execution, TENNESSEAN (May 1, 2014, 11:05 PM), http://www.tennessean.com/story/opinion/editori als/2014/05/02/botching-just-grisliest-argument-execution/8577729/.

96. See Lawrence Hummer, Opinion, Botched or Not, Executions Go Against Basic Humanity, U.S. NEWS \& WORLD REP. (July 28, 2014, 5:00 PM), http://www.usnews.com/de bate-club/do-botched-executions-make-the-case-for-abolishing-the-death-penalty/botchedor-not-executions-go-against-basic-humanity.

97. See SARAT, GRUESOME SPECTACLES, supra note 4, at 148.

98. See id. at 146-75 (discussing the history of botched executions and their impact on the capital punishment discourse).

99. See $i d$. at 175 (" $[\mathrm{U}]$ nlike issues of racial justice in the administration of the death penalty or advancements in the science of DNA which have fueled the innocence movement, botched executions have not moved sentiment, or galvanized opposition, to state killing itself."); see also id. at 167 ("The years leading up to the national moratorium in the late 1960s were a time of transition and uncertainty for America's death penalty. Botched executions, however, remained in the background."). 
snalty, but the bruthere-botched ex-

acles, it is not the "cultural reception" sr sociopolitical disrtunes? Or do they ite? ${ }^{98}$ Interestingly, not moved public t politics ${ }^{99}$ — and he is book. Ironically, at characterization

\section{TIONS AND THE}

\section{ECTION}

state responses to impact the constine of this writing,

http://www.concord moniren-more-barbaric; James ws Again Why the Death tp://www.washingtonpost. ed-execution-shows-again inion, There is No Such $4 \mathrm{PM})$, http://takingnote. xecution/?_r=0; Opinion, 24, 2014, 5:56 PM), http: nonstrates-debacle-ofment Against Execution, com/story/opinion/editori 91.

utions Go Against Basic tp://www.usnews.com/de death-penalty/botched-

ions and their impact on ainistration of the death ed the innocence movezed opposition, to state ional moratorium in the death penalty. Botched

the Supreme Court's only pronouncement on the constitutionality of lethal injection is its 2008 decision in Baze v. Rees, which upheld Kentucky's three-drug protocol. ${ }^{100}$ Although Baze was a deeply splintered decision, ${ }^{101}$ its takeaway was relatively clear: execution by lethal injection violates the Eighth Amendment's Cruel and Unusual Punishments Clause only when the protocol used poses "substantial risk of serious harm" in light of alternatives that are "feasible, readily implemented, and in fact significantly reduce a substantial risk of severe pain." ${ }^{102}$ How might state responses to botched executions play into this analysis?

Perhaps they don't. One might plausibly conclude that how a state handles the backside of a botched execution is its own business, just like any other public relations mess.

But one might also plausibly conclude that what a state does (or does not do) in response to a botched execution is constitutionally significant under Baze. Botched executions put the state on notice that there was a problem-perhaps with the drug protocol, or the dosage administered, or the manufacturer of the drugs, or the training of the execution team, or whatever else might have gone wrong. The question, then, is this: Do states have a responsibility under Baze to figure out what the problem is and fix it before conducting further executions?

Oklahoma's continued use of midazolam in its lethal injection protocol-and the Supreme Court's recent grant of certiorari in Glossip v. Gross ${ }^{103}$ - takes the question out of the realm of the purely hypothetical. After Clayton Lockett's botched execution, Oklahoma spent over $\$ 100,000$ to renovate its execution chamber. ${ }^{104}$ New and improved equipment, more room in the execution chamber, less space for media witnesses. ${ }^{105}$ Oklahoma also altered its lethal injection protocol, but not to replace midazolam, the

100. 553 U.S. 35, 41, 44 (2008); see infra notes 117-18 and accompanying text for a discussion of the Supreme Court's January 2015 grant of certiorari in Glossip v. Gross.

101. The Baze opinion represented the views of a three-Justice plurality, and was one of seven opinions in the case. See id. at 39.

102. Id. at 50-52 (citations omitted).

103. See Warner v. Gross, 776 F.3d 721 (10th Cir. Jan. 12, 2015), cert. granted sub nom. Glossip v. Gross, 83 U.S.L.W. 3625 (U.S. Jan. 23, 2015) (No. 14-7955).

104. Sean Murphy, Oklahoma Prison Officials Unveil New Death Chamber, Assoc. PRESS (Oct. 9, 2014, 8:04 PM), http://bigstory.ap.org/article/7161cb590cec47778a8f87f5d6 d05fd8/oklahoma-prison-officials-unveil-new-death-chamber.

105. See id. 
drug used in three of 2014's four botched lethal injections-that of Lockett, McGuire, and Wood. ${ }^{106}$ Instead, Oklahoma upped the amount of midazolam injected from one hundred milligrams to five hundred. ${ }^{107}$ Oklahoma claims that Lockett's botched execution was caused by the failure of his IV line, so concerns about the drug are inapposite. ${ }^{108}$

But the use of midazolam in executions is extremely controversial because it is a sedative, not an anesthetic. ${ }^{109}$ It is also subject to a so-called "ceiling effect" upon saturation in the body. ${ }^{110}$ As one anesthesiologist explained, "[I]t doesn't matter if you give the person 500 additional doses or five million doses. It won't have any more effect."111 The problem is the drug, not the dosage. And that's especially problematic for Oklahoma executions because the state's three-drug protocol follows midazolam with a paralytic, so unless the injection of the paralytic goes awry (as it did in Lockett's case), the condemned will be paralyzed and unable to express pain. ${ }^{112}$ Indeed, that may be the very point. ${ }^{113}$

In January 2015, four Oklahoma death row inmates appealed to the U.S. Supreme Court for a stay of execution while they litigated Oklahoma's protocol. ${ }^{114}$ The Supreme Court voted five-four to deny the stays, with Justice Sotomayor writing for the four Justices in dissent that she was "deeply troubled by this evidence suggesting that midazolam cannot be constitutionally used as the

106. Moni Basu, Botched Oklahoma Execution Haunts Inmate as Death Nears, CNN (Jan. 15, 2015, 10:26 PM), http://www.cnn.com/2015/01/15/us/oklahoma-resumes-execu tions/; Adam B. Lerner, Oklahoma Prepares to Use Controversial Execution Drug, POLITICO (Jan. 15, 2015, 12:07 PM), http://www.politico.com/story/2015/01/oklahoma-exe cution-death-penalty-114266.html.

107. See Robert Barnes \& Mark Berman, Supreme Court Will Review Lethal Injection Drug Protocol Used in Executions, WASH. Post (Jan. 24, 2015), http://www.washington post.com/politics/courts_law/supreme-court-will-review-lethal-injection-drug-protocol-usedin-executions/2015/01/23/10841c10-a347-11e4-9f89-561284a573f8_story.html.

108. See Basu, supra note 106; Lerner, supra note 106.

109. See Lerner, supra note 106.

110. Warner v. Gross, 574 U.S. - (2015) (No. 14-7955), at 3 (Sotomayor, J., dissenting in denial of stays of execution), available at http://www.supremecourt.gov/opinions/14pdf /14a761_d1 8f.pdf (discussing the "ceiling effect" of midazolam).

111. Santos, supra note 70.

112. See Lerner, supra note 106; Warner, No. 14-7955, at 6 (Sotomayor, J., dissenting) ("The deficiency of midazolam may generally be revealed only in execution, such as Lockett's, where the IV fails to sufficiently deliver the paralyzing agent.").

113. See Basu, supra note 106 (noting that the paralytic agent is used "to prevent the inmate from flailing").

114. Warner, No. 14-7955, at 1 (Sotomayor, J., dissenting in denial of stays of execution, joined by Justices Ginsberg, Breyer, and Kagan). 
al injections-that ahoma upped the red milligrams to botched execution oncerns about the

extremely controc. ${ }^{109}$ It is also sub1 in the body. ${ }^{110}$ As ter if you give the ies. It won't have $t$ the dosage. And recutions because $m$ with a paralytawry (as it did in ed and unable to nt. $^{113}$

inmates appealed on while they litirt voted five-four ting for the four by this evidence nally used as the

as Death Nears, CNN klahoma-resumes-execu ersial Execution Drug, y/2015/01/oklahoma-exe

Review Lethal Injection http://www.washington ion-drug-protocol-usedtory.html.

tomayor, J., dissenting ourt.gov/opinions/14pdf

omayor, J., dissenting) recution, such as Lockis used "to prevent the nial of stays of execu- first drug in a three-drug lethal injection protocol."115 The dissenting opinion discussed all three of 2014's botched executions using midazolam. ${ }^{116}$ For at least four members of the Court, it would appear that a state's response to botched executions is highly relevant under Baze.

A week later the Supreme Court granted certiorari to consider Oklahoma's use of midazolam in its lethal injection protocol, but by then the case had three death row inmates rather than four. ${ }^{117}$ The litigation that began as Warner became Glossip v. Gross. ${ }^{118}$ Now the country watches, and waits. Until the Court decides Glossip, the Attorney General of the United States has called for a moratorium on executions, ${ }^{119}$ and at least one death dealing state, Florida, has heeded that call based on "a reasonable and realistic chance of [its lethal injection protocol] being declared to be cruel and unusual punishment by the United States Supreme Court." 120

Of course, how the intersection of constitutional doctrine and the politics of botched executions will play out in Glossip is anyone's guess. But this much is clear: The state responses to botched executions in 2014 will almost certainly mean more botched executions in the future. And that could be a problem for death penalty states when the Supreme Court decides Glossipbecause it's not just executions that states have botched, but their responses as well.

115. Id. at 7; Richard Wolf \& Gregg Zoroya, Oklahoma Executes Man After Justices Deny Stay, USA TODAY (Jan. 16, 2015, 9:10 AM), http://www.usatoday.com/story/news/na tion/2015/01/15/supreme-court-oklahoma-execution-drug/21828129/.

116. See Warner, No. 14-7955, at 1-2 (Sotomayor, J., dissenting in denial of stays of execution).

117. See Wolf \& Zoroya, supra note 115; Lawrence Hurley, Supreme Court to Review Oklahoma Execution Procedure, REUTERS (Jan. 23, 2015), http://www.reuters.com/article/ 2015/01/23/us-usa-court-deathpenalty-idUSKBNOKW2GP20150123.

118. Warner v. Gross, 776 F.3d 721 (10th Cir. Jan. 12, 2015), cert. granted sub nom. Glossip v. Gross, 83 U.S.L.W. 3625 (U.S. Jan. 23, 2015) (No. 14-7955); see also Adam Liptak, Execution Case Highlights the Power of One Vote, N.Y. Times, Jan. 26, 2015, at A13. Stays were subsequently granted for the remaining three petitioners. See Adam Liptak, Justices Stay Executions of 3 in Oklahoma Pending Decision on Lethal Drug Protocol, N.Y. TIMES, Jan. 29, 2015, at A14.

119. See Adam Edelman, Eric Holder Backs Death Penalty Moratorium Until U.S. Supreme Court Ruling, N.Y. DAILY NEWS (Feb. 18, 2015), http://www.nydailynews.com/news /politics/holder-backs-death-penalty-moratorium-scotus-ruling-article-1.2120017.

120. See Correll v. Florida, SC15-147, Florida Supreme Court (Feb. 17, 2015), available at http://www.floridasupremecourt.org/pub_info/summaries/briefs/15/15-147/Filed_02-172015_Order_Granting_Stay.pdf. 